\title{
Holistic Education through Athletics: Health and Health- Literacy of Intercollegiate Athletes and Active Undergraduate Students
}

\author{
Erianne A. Weight, $\mathrm{PhD}$ \\ University of North Carolina at Chapel Hill \\ Kristina M. Navarro, PhD \\ University of Wisconsin-Whitewater
}

\author{
Abbie Smith-Ryan, $\mathrm{PhD}$ \\ The University of North Carolina at Chapel Hill \\ Landon T. Huffman, PhD \\ Johnson University
}

\begin{abstract}
The purpose of this research was to examine select psychological (body awareness), educational (health, nutrition, and injury recovery knowledge) and physiological (height, weight, BMI, and body fat percentage) variables within a sample of university students $(n=914)$ and varsity athletes $(n=435)$ at three "Power 5" NCAA Division I institutions in an effort to explore the legitimacy of competitive athletics as a holistic educational endeavor worthy of fulfilling the mission of higher education. Data analysis revealed some support for Kolb's experiential learning theory, with athletes demonstrating significantly greater nutrition, health, injury knowledge, and body awareness than non-athletes $(p<0.01)$, though mean scores for both groups revealed limited knowledge. Athletes demonstrated overall superior health and lower susceptibility to future metabolic risk factors than their active non-athlete classmates as demonstrated by a significantly lower body fat percentage despite having higher BMI values. Despite a lack of structured traditional education, it appears that athletes are gaining knowledge and engaging in practices critical to holistic development. Practitioners must determine how to further cultivate these benefits through structured education for athletes and non-athletes.
\end{abstract}

Through each developmental era of athletics in higher education, a philosophical tension has arisen between the sanctity of the academy as a forum for meaningful learning and the competitive commercial enticements of athletics that can facilitate unprincipled behavior based upon a win-at-all costs mentality (Byers \& Hammer, 1995; Desrochers, 2013; Oriard, 2001; Smith, 2011; Thelin, 1996). The National Collegiate Athletic Association (NCAA) and its actors have been questioned in an expanding body of literature and litigation which condemns excessive financial spending (Anthes, 2010; Drape \& Thomas, 2010; Fulks, 2011); manipulation and mistreatment of athletes (Elinson, 2013; McCormick \& McCormick, 2006; Sack \& Staurowsky, 1998; Zimbalist, 1999); and media frenzy within intercollegiate athletics that undermines undergraduate education and university operation (Benford, 2007; Duderstadt, 2003; Sperber, 2000; Weight \& Cooper, 2012). The recent changes to conference alignment and commercialization of sport among the Power 5 conferences continue to intensify such scrutiny of this athletics and academics divide. 
Driven by this philosophical divide within the academy, the purpose of this study was to address an important literary gap through measuring a variety of psychological and physiological constructs within a sample of active university students and varsity athletes. Specifically, the focus of this study was to quantify the legitimacy of athletics as an educational endeavor geared toward producing future societal leaders (Brand, 2006). This research is approached through Kolb's theoretical lens of experiential learning. Utilizing this theoretical lens, we considered how purposeful engagement, experiential learning, and holistic development during intercollegiate athletics participation should demonstrate quantifiable benefits with respect to lifelong personal health and wellness. The findings of the study are important to the literature and surrounding critical commentary of college sport as they provide quantifiable constructs indicative of holistic education. This data can add depth to the current discussions of reform, exploitation, and education within intercollegiate athletics by examining important aspects of individual well-being not typically addressed. Toward this end, the following research questions were pursued.

\section{Research Questions}

[RQ 1] Do athletes view their intercollegiate athletic experience as educational? [RQ 2] What educational benefits are most highly valued by intercollegiate athletes? [RQ 3] Are there significant differences in basic health measures and knowledge between athletes and non-athletes?

[RQ 4] Are there significant differences in basic health measures and knowledge based on sex, class standing, race, GPA, or participation in high school sport?

\section{Literature Review}

Higher education administrators are becoming increasingly conscientious of the intersection between students' academic pursuits and personal development. Subsequently, a holistic care approach evaluates the higher education experience as a comprehensive endeavor integrating physical, mental, emotional, social, and spiritual dimensions of humanity (Forbes, 2003; Miller, 2006; Myers, Sweeney, \& Witmer, 2000; Schreiner, 2009; Schreiner, Banev, \& Oxley, 2005; Weight, 2015; Weight, Navarro, Huffman, \& Smith-Ryan, 2014;). Given an increased emphasis on health from a 360-degree perspective, college student development models are evolving to be inclusive of wellness beyond mere physical health so as to enhance the overall educational experience (Watson \& Kissinger, 2007). Building upon this holistic education framework, we will examine literature exploring the role of athletics within the academy, health literacy, and education through athletics.

\section{The Role of Athletics within the Academy}

A clear disconnect is evident within the literature base with respect to how varsity athletes may best balance and navigate dual roles as both students and athletes. While practitioners continue to search for ways to support athletes within an omnipresent athletecentric media model, scholars seek to better understand how to quantify and qualify the benefits of participation in athletics at the Division I level. To this end, many of the reform-based arguments surrounding intercollegiate athletics have been tempered by literature documenting athletics' ability to enliven a campus community, provide a positive outlet for purposeful engagement, and build a university brand (Smith, 1988; Stevens, 2007; Toma, 1999). At big time schools, metrics which demonstrate increases in athletic donations, applications, academic 
reputation, in-state enrollment, and incoming student SAT scores, specifically demonstrate the ability of athletics departments to enhance the campus culture as a whole and the benefits derived from a positive university brand (Anderson, 2008; Bremmer \& Kesselring, 1993; Grimes \& Chressanthis, 1994; Humphreys \& Mondello, 2007; McCormick \& Tinsley, 1987; Mixon, Trevino, \& Minto, 2004; Pope \& Pope, 2009; Tucker \& Amato, 1993). While much of this data outlines the impact of athletics on the academy, there is little research that outlines the impact of athletics on the athlete. Researchers must continue to demonstrate how the college athletics experience can prepare students for success in life after college via holistic development.

Some scholars have supported the presence of athletics in the academy by exploring the fundamental notion that athletics is a unique element of holistic education (Adler \& Adler, 1991; Bonfiglio, 2011; Bowen \& Levin, 2003; Brand, 2006; Weight et al., 2014; Weight, Cooper, \& Popp, 2015; Weight, 2015). To date, however, many of these developmental benefits have not been quantified with empirical research, and additional inquiry is necessary to understand the value of an intercollegiate athletics experience.

\section{Recent Shifts in NCAA Structure}

As we explore the educational value of intercollegiate athletics, it is important to understand the context of the Power 5 athletics sample and the structural issues that may affect optimal educational experiences. In August of 2014, the NCAA Division I Board of Directors granted autonomy to the 64 schools in the richest five conferences (the ACC, Big 12, Big Ten, SEC and Pac-12) that had threatened to leave the NCAA unless granted autonomy to enact legislation unique to their interests (Hosick, 2014; Wolken, 2014). Thus, the Power 5 was created. Many of the initiatives these institutions sought to implement were athlete-centric, including the ability to offer additional compensation, loosen agent restrictions, and offer compensation for players' families to attend postseason games (Bennett, 2014; Weight \& Zullo, 2015; Wolken, 2014). This formal governance shift is troubling to some who believe it will hasten the arms race of extravagant expenditures and cause institutions to lose site of the importance of supporting holistic athlete development (Dosh, 2014; Sneed, 2014; Terlep, 2014).

The arms race has been pursued at all levels of intercollegiate athletics, but some of the most detrimental effects of the spending are clearest at the Division I Power 5 level where the money has been most abundant. At this level, we have seen a proliferation of new athlete-only workout centers, entertainment lounges, practice facilities and study centers often miles away from "main campus" that structurally isolate athletes from the rest of the university population (Duderstadt, 2012; Frey, 2012). While one stop shop athlete performance centers may suggest a focus is being placed on student development, the debate of whether such models are conducive to holistic development and purposeful engagement in the academic community continues in the student affairs literature. This structural isolation can exacerbate other forms of athlete isolation that have been documented in the literature within Division I institutions including feelings of "otherness" due to time demands (Adler \& Adler, 1991), racial isolation (Rhoden, 2010; Sellers, Kuperminc, \& Damas, 1997), and academic isolation in the form of major clustering (Fountain \& Finley, 2009; Fountain \& Finley, 2011; Schneider, Ross, \& Fisher, 2010). Clear reform and data driven practices are needed to understand the athlete experience; and, more specifically, the impact participation in athletics can bring not only to varsity athletes, but to campus as a whole.

\section{Health Literacy}


Health literacy is an important component of health care in the United States, encompassing the capacity to obtain and process basic health information (United States Department of Health and Human Services, 2000). In 2008, the Institute of Medicine (IOM) demonstrated that health literacy in the US was alarmingly low, and explained that reduced or deficient health literacy had a stronger influence on overall health than age, income, employment states, education, or race (Institute of Medicine, 2004).

Culminating literature suggests that individuals who perceive their health status as good, engage in healthier behaviors, seek health information, and may improve the utilization of health information more effectively (Baker, Wagner, Singer, \& Bundorf, 2003; Huang \& Chiou, 1997; Institute of Medicine, 2004). For example, previous data demonstrate students enrolled in medical-related majors engaged in healthier habits and health promoting lifestyles (Huang \& Chiou, 1997; Hsu, Chiang, Yang, 2014). Additionally, college-educated individuals are thought to have higher than average health literacy rates, thereby suggesting a concomitant participation in positive health behaviors (Stellefson et al., 2011). Due to the general health-promoting environment of sport, athletics lends itself to be fertile grounds for promoting positive health behaviors, but this has yet to be evaluated. Athletics may further improve health literacy due to individual and environmental components, thus yielding life-long effects on positive health behaviors. To date, the effects of college athletics on health literacy or health behaviors has not yet been evaluated.

\section{Education through Athletics}

Research into the cognitive, psychological, and emotional impact of intercollegiate athletics participation has produced conflicting findings. Several scholars have cataloged negative collegiate experiences for varsity athletes, particularly between football and men's basketball minority athletes and traditional students (Blann, 1985; College Sport Research Institute, 2014; Fountain \& Finley, 2009; Lanter \& Hawkins, 2013; Maloney \& McCormick, 1993; Southall \& Weiler, 2014; Sowa \& Gressard, 1983; Stone \& Strange, 1989). Other studies have produced findings that substantiate the unique benefits of participating in intercollegiate athletics. For example, athletes are aware of the psychological and social benefits gleaned from intercollegiate athletic participation (Singer, 2008). In a study by Potuto and O'Hanlon (2007), more than $90 \%$ of collegiate athletes agreed that athletic participation had strongly influenced their leadership skills, teamwork, work ethic, ability to take responsibility for oneself, decisionmaking ability, and time management skills. Videon (2002) added, "athletics...develop[s] numerous estimable qualities such as self-discipline, perseverance, hard work, sacrifice, teamwork, respect for rules, and interpersonal skills" (p. 420).

Scholars have explored many educational outcomes of intercollegiate athletics including: (a) increased educational engagement \& graduation rates (Howard-Hamilton \& Sina, 2001; Long \& Caudill, 1991; Pascarella \& Terenzini, 2005; Rishe, 2003; Umbach, Palmer, Kuh, \& Hannah, 2006); (b) self-esteem and character development (Astin, 1993; Hirko, 2009; Pascarella \& Smart, 1991; Potuto \& O'Hanlon, 2007; Singer, 2008; Videon, 2002); (c) time management skills (Bonfiglio, 2011); (d) rate of growth and cognitive development (Chaddock, Neider, Voss, Gaspar, \& Kramer, 2011; Rosewater, 2009; University Learning Outcomes Assessment, 2011); and (e) enhanced marketability upon graduation (Chalfin, Weight, Osborne, \& Johnson, 2015; Long \& Caudill, 1991; McCann, 2012; Shulman \& Bowen, 2011; Soshnick, 2013; Williams, 2013). 
While studies have documented many participant benefits, it is critical to emphasize participation itself does not guarantee these aforementioned outcomes, which could partially explain the mixed results (Bonfiglio, 2011; Gayles \& Hu, 2009; Howard-Hamilton \& Sina, 2001; Watson \& Kissinger, 2007). Specifically, the more students are involved - with respect to time and effort - in a learning experience (such as intercollegiate athletics), the greater the developmental outcome (Gayles, 2009; Gayles \& Hu, 2009). Additionally, cognitive development is enhanced when participants are exposed to multicultural relationships, communities, and experiences (Hirko, 2009; Wolf-Wendel, Douglas, \& Morphew, 2001). Without a doubt, intercollegiate athletics has the capability to foster a multicultural environment that links athletes "across most differences, including race, socioeconomic status, and geographic background" (Wolf-Wendel et al., 2001, p. 376). There are documented educational outcomes of intercollegiate athletics participation, but further research is needed to investigate and maximize the impact of these athlete-educational experiences.

\section{Theoretical Framework}

To frame this study and better understand the educational potential of the athlete experience, we draw on Kolb's (1984) Experiential Learning Theory (ELT), often defined as "learning through reflection on doing" (Patrick, 2011, p. 1003). This theory is widely utilized within student affairs literature, yet, is rarely applied to the athlete higher education population subset. ELT provides a holistic model of the learning process. While many learning theories focus on cognition and behavior, this theory focuses on how actual life experience influences one's learning and development. To further understand how students grow and develop as holistic individuals, Kolb presents a four stage cyclical model of student learning. He suggests that learners progress through specific periods (e.g., concrete experience, reflective observation, abstract conceptualization, and active experimentation) as they interact with new environments. Drawing on the work of John Dewey, Kurt Lewin, and Jean Piaget, Kolb asserts that learning is a process whereby knowledge is created through transformative experiences (Dixon, Adams \& Cullins, 1997).

In the context of this study, we consider whether learners progress through stages during the higher education experience as athletes. For example, an athlete who participates in track and field may gain knowledge about nutrition through experiences on the track. Depending on what she ate on a given day of intense training, she may perform well or collapse (concrete experience). This experience may lead to reflection on the nutritional value of her daily meals (reflective observation), or a coach insisting she see a nutritionist, which then may lead her to further reflective observation through which she can learn from the experience (abstract conceptualization). Based on her reflection and learning, and possibly concrete guidance from a coach or a nutritionist, she may plan and try out what she learned through alternative meal planning (active experimentation), which will then lead to unique (concrete) experiences. This cycle could be applicable to other facets of the athletics arena including strength and conditioning methods, experiences with success or failure on the track, communication within the team, etc.

There is a substantial literary foundation exploring the application of Kolb's ELT to higher education and college students. Many of these previous studies have focused on nontraditional college students applying their previous work experience (Chaves, 2006; RossGordon, 2003) or the learning style of college students (Barber, 2012; Jones, Reichard, \& Mokhtari, 2003; Matthews, 1991). ELT has also been used in association with specific student 
sub-populations such as hospitality students and Latinos (Hsu, 1999; Teranishi, 2007) and with the impact of education experiences encountered by college students (e.g. study abroad) (Shames \& Alden, 2005; Younes \& Asay, 2003). Experiential learning and metadiscrete experiential learning models have been extensively researched as effective methods of sport management education (Bruening, Madsen, Evanovich, \& Fuller, 2010; Hardin, Bemiller, \& Pate, 2013; Irwin, Hays \& Irwin, 2011; McKelvey \& Southall, 2008; Pauline, 2013; Pauline \& Pauline, 2008; Pierce, \& Petersen, 2010; Southall, Nagel, LeGrande, \& Han, 2003; Spence, Hess, McDonald, \& Sheehan, 2009; Walker \& Lim, 2007), but there is a lack of literature applying the theory to education through athletics.

We draw on Kolb's (1984) theory to understand how athletes interpret their higher education experience as an educational, holistic and transformative endeavor. We specifically consider how athletes' knowledge of salient physiological experiences in higher education compares to non-athletes. We consider how knowledge of these physiological components of the athlete experience influences perceptions of the higher education experience as transformative and influential to future success in life after sport. Moreover, this theory frames our discussion on how the athlete experience may provide additional educational benefits for this higher education population subset and warrants the placement of intercollegiate athletics within higher education.

To this end, this study draws on the major tenets of Kolb's theory to understand how the athlete experience influences overall wellbeing, health and wellness via intentional focus on lifelong wellbeing. We draw on this theory to quantify and qualify the benefits of the athlete experience by considering specific measures of physiological development coupled with knowledge of health and wellness. ELT frames our discussion on how the athlete experience may provide additional physiological and holistic benefits for athletes and demonstrates a clear data driven benefit for athletics participation. As intercollegiate athletics are already a segment within the academy that is largely publicly subsidized and highly scrutinized, this research provides an exploratory view into the educational value of intercollegiate athletics with an emphasis on select physiological variables and knowledge of health and wellness.

\section{Instrument}

\section{Method}

The population of interest was athletes and active students from institutions affiliated with "Power 5" Football Bowl Subdivision athletic conferences in the NCAA (discussed in detail in the Data Collection subsection). In order to draw a broad sample that would facilitate generalizability, the research was conducted through survey methodology. A 37-item instrument composed of standard demographic questions and 15 embedded subscales measuring psychological, physiological, and intellectual measures was utilized. For this study the demographic measures of interest included questions of sex, race, age, class standing, grade point average, age when participation in competitive sport began, sport (for athlete sample), extent of participation in high school or youth sport, weight, height, and body fat percentage. Of the fifteen embedded subscales included in the broader survey, four were of interest for this study. These scales measured body awareness (Shield, Mallory, \& Simon, 1989), general health knowledge, nutrition knowledge, and injury-recovery knowledge. In addition to these questions, there was one Likert-scale and one open-ended question for the athlete sample related to their perceptions of the educational value of participation in intercollegiate athletics.

Body fat percentage measures were self-reported, but all respondents had been measured via bioelectrical impedance analysis (Omron HBF-306C) within a two-months of having taken 
the survey via a fitness course or athletics physical, and respondents were prompted that if they did not remember their latest measurement to leave the response field blank. Body awareness was measured utilizing the Body Awareness Questionnaire, which has been refined through multiple measures of validity and has demonstrated high reliability coefficients through extensive empirical research (Shields, Mallory, \& Simon, 1989). The three measures of healthrelated knowledge were developed by combining established test questions representing concepts of mastery from disciplines of health, nutrition, and injury-treatment (Pescatello, 2014; Antonio, 2008). Scale internal consistency measures were all in the "acceptable," "good," and "excellent" ranges (George \& Mallery, 2003; Streiner, 2003) and are listed in Table 2.

Specific to the health, nutrition, and injury-treatment subscales, questions were gleaned (though slightly modified) from leading textbooks and mastery resource test-banks in the domains of interest (Pescatello, 2014; Antonio, 2008). The entire instrument was reviewed by a survey design consultant from the Odum Institute, an organization designed to aid in the advancement of social science research. Additionally, the survey was reviewed by a panel of eleven individuals deemed experts in the area in an effort to ensure validity of the instrument as a whole. The panel of experts included three sport administration researchers, a practicing sport psychologist, a university student counselor, a researcher with a focus in psychological scales, a physiology researcher with an area of expertise in sport nutrition, two varsity athletes, and two active non-athlete undergraduate students.

\section{Data Collection}

Surveys were distributed via Qualtrics to a large subset of students participating in lifetime fitness courses and all athletes from three institutions representing the Big Ten, Atlantic Coast, and Southeastern conferences. Athlete surveys were sent directly to the respondents using institutional email addresses and yielded a response rate of $27.12 \%(n=435)$. Non-varsity athlete participants were invited via lifetime fitness instructor emails and yielded $(n=914)$ responses. Due to the inability to track instructor follow-through in dissemination, the response rate for lifetime fitness participants was immeasurable, but the maximum possible number of participants within the courses was approximately 6200 which equates to a minimum possible response rate of $14.74 \%$ (Weight et al., 2014).

\section{Data Analysis}

Missing data analysis was conducted in order to address patterns of missingness in the data. Of the 1,349 total responses, case-wise deletion was utilized on $10 \%$ of the cases which had no information for the independent variables and subsequently no utility. Of the remaining observations, $95 \%$ ( $n=1143$ ) were complete. Given the high completeness rate among usable observations, listwise deletion was used to define the samples used in the analyses. Data were analyzed utilizing multiple one-way analyses of variance with independent variables of intercollegiate athlete status, sex, class standing, race, age, grade point average, "revenue" sport, and participation in high school or youth sport tested. One-way analysis of variance was chosen as the optimal method due to different patterns of missingness on the outcomes that would result in unacceptable information loss if MANOVA were utilized. Additionally, an omnibus hypothesis was not being tested, thus one-way analyses of variance were the most efficient statistical tests for the research questions addressed in the study. Quantitative data were analyzed utilizing Statistical Package for Social Sciences (SPSS) 20.0 (Weight et al., 2014). 
Qualitative data from the open-ended question asked of the 240 athletes that rated the educational experience of participation in intercollegiate athletics as "very useful" or "useful" were independently organized into emergent categories by two researchers based on the nature of the responses to a question asking "what are some of the most valuable lessons you have learned from your participation in intercollegiate athletics" $(n=155)$. Eleven categories emerged after two rounds of code modification (Saldaña, 2009). After finalizing the code, data was independently coded yielding a Krippendorff's Alpha of 0.912 reflecting $92.3 \%$ (high level) agreement between coders.

\section{Sample Demographic Information}

\section{Results}

The sample was primarily composed of Caucasian $(n=925 ; 80.9 \%)$, female $(n=788$; $68.9 \%$ ) respondents with a fairly even split in respondent class standing (see Table 1). Every NCAA sport was represented in the athlete sample, with an independent variable of "revenue" sport athlete composed of 19 football and six men's basketball players $(n=25 ; 6.8 \%)$. Based on the target population, these response rates demonstrated over-representation of Caucasian respondents, women, and Olympic sport athletes, and under-representation of African Americans, football, and basketball players. All other categories were reflective of the target population. These sampling errors are addressed through analysis of the gender, "revenue" sport, and ethnicity independent variables (Weight et al., 2014).

Average age for athletes $(M=19.89 ; S D=1.490)$ and non-athletes were similar $(M=$ 19.26; $S D=1.582$ ), and the median GPA for both groups was in the 3.0-3.49 category. Both athlete and non-athlete groups shared the median category of participation in organized competitive athletics beginning between 5-8 years old. Athletes indicated a higher number of hours per week spent in organized competitive high school sport with the median of 10+ hours/week, while non-athletes median was within the moderate category of 5-10 hours per week (Weight et al., 2014).

Table 1

Demographic Information

\begin{tabular}{|c|c|c|c|c|c|c|c|}
\hline & & \multicolumn{4}{|c|}{ Intercollegiate Athlete (ICA) Status } & \multirow{2}{*}{\multicolumn{2}{|c|}{ All }} \\
\hline & & \multicolumn{2}{|c|}{ Non-ICA } & \multicolumn{2}{|c|}{ ICA } & & \\
\hline & & $\%$ & $n$ & $\%$ & $n$ & $\%$ & $n$ \\
\hline \multirow[t]{2}{*}{ Sex } & Male & $31.2 \%$ & 242 & $30.9 \%$ & 114 & $31.1 \%$ & 355 \\
\hline & Female & $68.8 \%$ & 533 & $69.1 \%$ & 255 & $68.9 \%$ & 787 \\
\hline \multirow[t]{5}{*}{ Race } & Caucasian & $80.1 \%$ & 620 & $82.6 \%$ & 304 & $80.9 \%$ & 925 \\
\hline & African- American & $4.9 \%$ & 38 & $7.9 \%$ & 29 & $5.9 \%$ & 67 \\
\hline & Hispanic & $5.3 \%$ & 41 & $3.3 \%$ & 12 & $4.6 \%$ & 53 \\
\hline & Asian & $6.3 \%$ & 49 & $3.1 \%$ & 11 & $5.2 \%$ & 60 \\
\hline & Other & $3.5 \%$ & 27 & $3.1 \%$ & 11 & $3.3 \%$ & 38 \\
\hline \multirow[t]{4}{*}{ Class } & Freshman & $27.9 \%$ & 216 & $29.3 \%$ & 108 & $28.4 \%$ & 324 \\
\hline & Sophomore & $25.1 \%$ & 194 & $23.3 \%$ & 86 & $24.5 \%$ & 280 \\
\hline & Junior & $23.4 \%$ & 181 & $17.9 \%$ & 66 & $21.5 \%$ & 247 \\
\hline & Senior & $22.2 \%$ & 172 & $24.0 \%$ & 88 & $22.9 \%$ & 260 \\
\hline
\end{tabular}


$N=1143$

\section{Measures of Health Benefits and Knowledge of Varsity Athletes and Active Students}

The athlete and active student samples were significantly different in reported physiological measures with the athletes on average 21 pounds heavier, 2.58 inches taller, and $5.19 \%$ leaner than the active student sample (see Table 2 for specific statistical measures), indicating overall greater muscle mass and lower body fat among the athlete population. Not surprisingly given this data indicating wide fluctuation in lean mass, the BMIs which do not account for fat or lean mean scores for body awareness were slightly, though non-significantly higher for athletes than non-athletes, and mean scores for nutrition, health, and injury/recovery knowledge were all significantly greater for the athlete sample, though mean differences were minimal.

\section{Table 2}

Health measures and knowledge of intercollegiate athletes (ICA) and active undergraduate students

\begin{tabular}{|c|c|c|c|c|c|c|c|c|c|c|}
\hline & Min & Max & $\begin{array}{l}\text { ICA } \\
\text { Mean }\end{array}$ & $\begin{array}{c}\text { ICA } \\
\text { SD }\end{array}$ & $\begin{array}{l}\text { Non- } \\
\text { ICA } \\
\text { Mean }\end{array}$ & $\begin{array}{l}\text { Non- } \\
\text { ICA } \\
\text { SD } \\
\end{array}$ & $\begin{array}{c}\text { Mean } \\
\text { Difference }\end{array}$ & $\mathrm{F}$ & $p$ & $\alpha$ \\
\hline Weight (lbs)* & 85 & 330 & 167 & 39.43 & 146 & 27.2 & 21 & 16.76 & 0.000 & \\
\hline Height (in)* & 56 & 77 & 69.58 & 4.57 & 67 & 3.97 & 2.58 & 33.92 & 0.000 & \\
\hline BMI & 11.53 & 43.85 & 23.34 & 3.92 & 23.24 & 3.89 & 0.1 & 0.14 & 0.707 & \\
\hline Body Fat $\% *$ & 2 & 38 & 14.56 & 6.28 & 19.75 & 6.86 & -5.19 & 31.32 & 0.000 & \\
\hline Body Awareness & 6 & 30 & 22.13 & 4.68 & 20.39 & 4.35 & 1.74 & 5.68 & 0.017 & .699 \\
\hline Nutrition Knowledge* & 1 & 10 & 4.57 & 2.28 & 3.35 & 2.16 & 1.22 & 60.82 & 0.000 & .810 \\
\hline Health Knowledge* & 1 & 10 & 6.65 & 1.54 & 5.35 & 1.79 & 1.3 & 118.7 & 0.000 & .849 \\
\hline Injury/Recov Knowledge* & 1 & 12 & 8.65 & 1.92 & 6.44 & 2.75 & 2.21 & 159.86 & 0.000 & .911 \\
\hline
\end{tabular}

Each of the dependent variables were tested for significant differences based on participation status, sex, race, GPA, class standing, participation in "revenue" or "non-revenue" sports, and participation in high school sport. Several significant differences emerged within each dependent variable $(p<.01)$. Measures of weight were on average higher for athletes (compared to non-athletes), men (compared to women), those with GPAs below 2.99 (compared to those with GPAs above 3.00), and African American respondents (compared to Asian respondents), with the largest mean difference in weight between male $(M=175.5 \mathrm{lbs}$., $S D=$ 33.2 lbs.) and female respondents $(M=140.0 \mathrm{lbs}$., $S D=24.2 \mathrm{lbs}$.) with the male mean $35.5 \mathrm{lbs}$. heavier than the female respondents in the sample.

Four differences emerged in height within the independent variables of intercollegiate athletics participation, sex, race (Caucasians being taller than Asians), and high school participation (with those participating in extensive high school or youth sport competition on average taller than those who did not participate in high school or youth sport). Body fat percentages also differed significantly between several of the subgroups with athletes, men, and 
those who participated extensively in high school or youth athletics each with significantly lower body fat percentages than their comparison groups.

Table 3

Health Measures of intercollegiate athletes (ICA) and active undergraduate students by significant independent variables

\begin{tabular}{|c|c|c|c|c|c|c|c|c|c|}
\hline & Mean 1 & SD1 & Mean 2 & $S D 2$ & $\begin{array}{c}\text { Mean } \\
\text { Difference }\end{array}$ & $F$ & $p$ & Min & $\operatorname{Max}$ \\
\hline Weight (lbs) & 150.96 & 31.83 & & & & & & 85 & 330 \\
\hline ICA v. Non-ICA & 167.00 & 39.43 & 146.00 & 27.20 & 21.00 & 16.76 & .000 & & \\
\hline Male v. Female & 175.51 & 33.20 & 139.99 & 24.18 & 35.52 & 403.06 & .000 & & \\
\hline GPA $<2.99$ v. $>3.00$ & 162.71 & 40.70 & 149.66 & 30.01 & 13.05 & 20.99 & .000 & & \\
\hline African American v. Asian & 160.60 & 37.44 & 138.04 & 24.74 & 22.57 & 2.95 & .001 & & \\
\hline Height (in) & 67.37 & 4.29 & & & & & & 56 & 77 \\
\hline ICA v. Non-ICA & 69.58 & 4.57 & 67.00 & 3.97 & 2.58 & 33.92 & .000 & & \\
\hline Male v. Female & 71.36 & 3.23 & 65.49 & 3.35 & 5.86 & 742.48 & .000 & & \\
\hline Caucasian v. Asian & 67.58 & 4.33 & 65.16 & 3.21 & 2.42 & 3.86 & .000 & & \\
\hline Extensive v. No HS Comp & 67.88 & 4.31 & 66.14 & 3.89 & 1.74 & 10.97 & .000 & & \\
\hline BMI & 23.27 & 3.90 & & & & & & 12 & 44 \\
\hline Male v. Female & 24.13 & 3.89 & 22.91 & 3.75 & 1.22 & 23.44 & .000 & & \\
\hline GPA $<2.99$ v. $>3.00$ & 24.88 & 4.65 & 23.16 & 3.69 & 1.72 & 23.59 & .000 & & \\
\hline Hispanic v. Caucasian & 25.30 & 5.56 & 23.12 & 3.60 & 2.19 & 4.01 & .003 & & \\
\hline Body Fat (\%) & 17.65 & 7.06 & & & & & & 2 & 38 \\
\hline ICA v. Non-ICA & 14.56 & 6.28 & 19.75 & 6.86 & -5.19 & 31.32 & .000 & & \\
\hline Male v. Female & 12.60 & 6.11 & 20.84 & 5.62 & -8.24 & 202.75 & .000 & & \\
\hline Extensive v. Min HS Comp & 16.20 & 6.57 & 20.85 & 6.80 & -4.65 & 12.23 & .009 & & \\
\hline Extensive v. No HS Comp & 16.20 & 6.57 & 20.85 & 7.70 & -4.65 & 12.23 & .000 & & \\
\hline
\end{tabular}

Note: Tested for significant differences by intercollegiate athletics participation status, sex, race, GPA, class standing, "revenue" sport, and participation in high school sport. Subgroup statistics listed if $p<.01$.

As mentioned in Table 2, each of the health knowledge measurements were significantly different with athletes demonstrating significantly more body awareness and knowledge of nutrition, health, and injury recovery principles. Those with extensive high school sport participation also demonstrated significantly more awareness and knowledge in these measures of health knowledge than those who did not participate in high school sport, though in each of the four measures, the mean difference in sub-groups was the largest between varsity athletes and non-athletes. Other interesting findings with significant sub-group differences are outlined in Table 4.

Table 4 
Health knowledge measurements of intercollegiate athletes (ICA) and active undergraduate students by significant independent variables

\begin{tabular}{|c|c|c|c|c|c|c|c|c|c|}
\hline & $\begin{array}{c}\text { Mean } \\
1\end{array}$ & SD1 & Mean2 & $S D 2$ & $\begin{array}{c}\text { Mean } \\
\text { Diff }\end{array}$ & $\boldsymbol{F}$ & $p$ & Min & Max \\
\hline Body Awareness & 20.99 & 4.54 & & & & & & 7 & 30 \\
\hline ICA v. Non-ICA & 22.13 & 4.68 & 20.36 & 4.35 & 1.77 & 647.63 & 31.883 & & \\
\hline Caucasian v. Asian & 21.17 & 4.48 & 18.58 & 4.48 & 1.77 & 3.56 & .004 & & \\
\hline Nutrition Knowledge & 3.77 & 2.27 & & & & & & 1 & 10 \\
\hline ICA v. Non-ICA & 4.57 & 2.28 & 3.35 & 2.16 & 1.22 & 60.82 & .000 & & \\
\hline $\begin{array}{l}\text { Extensive v. No HS } \\
\text { Competition }\end{array}$ & 4.02 & 2.29 & 3.13 & 2.20 & .89 & 7.20 & .000 & & \\
\hline Health Knowledge & 5.79 & 1.82 & & & & & & 1 & 10 \\
\hline ICA v. Non-ICA & 6.65 & 1.54 & 5.35 & 1.80 & 1.30 & 118.70 & .000 & & \\
\hline $\begin{array}{l}\text { Extensive v. Minimal } \\
\text { HS C }\end{array}$ & 6.04 & 1.77 & 5.08 & 1.61 & .96 & 14.28 & .000 & & \\
\hline $\begin{array}{l}\text { Extensive v. No HS } \\
\text { Comp }\end{array}$ & 6.04 & 1.77 & 5.12 & 1.83 & .92 & 14.28 & .000 & & \\
\hline $\begin{array}{l}\text { Moderate v. No HS } \\
\text { Comp }\end{array}$ & 5.74 & 1.84 & 5.12 & 1.83 & .62 & 14.28 & .000 & & \\
\hline Freshmen v. Sophomore & 6.37 & 1.53 & 5.36 & 1.81 & 1.01 & 15.80 & .000 & & \\
\hline Freshman v. Junior & 6.37 & 1.53 & 5.43 & 1.89 & .94 & 15.80 & .000 & & \\
\hline $\begin{array}{l}\text { Injury Recovery } \\
\text { Knowledge }\end{array}$ & 7.20 & 2.71 & & & & & & 1 & 12 \\
\hline ICA v. Non-ICA & 8.65 & 1.92 & 6.44 & 2.75 & 2.21 & 159.86 & .000 & & \\
\hline $\begin{array}{l}\text { Extensive v. Min HS } \\
\text { Comp }\end{array}$ & 7.60 & 2.57 & 6.34 & 2.86 & 1.26 & 14.42 & .001 & & \\
\hline $\begin{array}{l}\text { Extensive v. No HS } \\
\text { Comp }\end{array}$ & 7.60 & 2.57 & 6.21 & 2.85 & 1.39 & 14.42 & .000 & & \\
\hline Freshmen v. Sophomore & 8.34 & 1.84 & 6.46 & 2.88 & 1.88 & 27.14 & .000 & & \\
\hline Freshman v. Junior & 8.34 & 1.84 & 6.42 & 2.99 & 1.92 & 27.14 & .000 & & \\
\hline Freshman v. Senior & 8.34 & 1.84 & 7.31 & 2.67 & 1.03 & 27.14 & .000 & & \\
\hline Sophomore v. Senior & 6.46 & 2.88 & 7.31 & 2.67 & -.85 & 27.14 & .004 & & \\
\hline
\end{tabular}

Note: Tested for significant differences by intercollegiate athletics participation status, sex, race, GPA, class standing, "revenue" sport, and participation in high school or youth sport. Subgroup statistics listed if $p<.01$. 


\section{Athlete Perceptions of the Educational Benefits of Athletics Participation}

In addition to physical measures and health-related knowledge, participants were given an opportunity to rate their educational experience in intercollegiate athletics. $85 \%$ $(n=240)$ ranked their experience as either somewhat or very useful, while $9 \%(n=24)$ were neutral, and $6 \%(n=18)$ felt their experience was either somewhat or very useless (see Table 5). Athlete respondents who rated their experience as educational were invited to elaborate through an open-ended question inquiring what the primary educational benefits of their intercollegiate athletics participation included (see Table 6). Topping the list were narratives describing experiences through athletics that enhanced selfconfidence and empowerment $(23 \%, n=35)$, and managing time and achieving balance $(23 \%, n=35)$. Other highly-mentioned educational benefits included teamwork and mutual empowerment $(16 \%, n=25)$, and connecting hard work to success $(10 \%, n=15)$. Only two respondents mentioned the physical or health related benefits (1\%).

Table 5

How Educational do you believe your experience in intercollegiate athletics has been?

\begin{tabular}{lcc}
\hline & $n$ & $\%$ \\
\hline Very Educational & 161 & $57 \%$ \\
Somewhat Educational & 79 & $28 \%$ \\
Neutral & 24 & $9 \%$ \\
Somewhat Useless & 12 & $4 \%$ \\
Very Useless & 6 & $2 \%$ \\
\hline
\end{tabular}

$N=282$

Table 6

Educational Benefits of Intercollegiate Athletic Participation

\begin{tabular}{lcc}
\hline & $n$ & $\%$ \\
\hline Managing time \& achieving balance & 35 & $23 \%$ \\
Self-confidence \& empowerment & 35 & $23 \%$ \\
Teamwork/mutual empowerment & 25 & $16 \%$ \\
Commitment - connecting hard work to success & 15 & $10 \%$ \\
Leadership \& professionalism & 9 & $6 \%$ \\
Striving for success & 8 & $5 \%$ \\
Respect for others & 8 & $5 \%$ \\
Performing under pressure & 7 & $5 \%$ \\
Accountability & 6 & $4 \%$ \\
Growth through adversity & 5 & $3 \%$ \\
Maintaining fitness \& health & 2 & $1 \%$ \\
\hline
\end{tabular}

$N=155$ 


\section{Discussion \& Implications}

[RQ 1] Do athletes view their intercollegiate athletic experience as educational? [RQ 2] What educational benefits are most highly valued by intercollegiate athletes?

[RQ 3] Are there significant differences in basic health measures and knowledge between athletes and non-athletes?

[RQ 4] Are there significant differences in basic health measures and knowledge based on sex, class standing, race, GPA, or participation in high school sport?

\section{Educational Benefits of Intercollegiate Athletic Participation}

Eighty-five percent of the athletes in this sample rated their experience in intercollegiate athletics as very or somewhat educational. Given the traditional "nonacademic," "auxiliary" view of athletics, the recognition of educational value by the vast majority of athletes is a strong indicator of educational value within this unit of the academy (Adler \& Adler, 1991; Bonfiglio, 2011; Bowen \& Levin, 2003; Brand, 2006; Chalfin et al., 2015; Weight, 2015).

A glimpse into the specific educational outcomes of the athlete experiences emerge from the open-ended questions. Stated educational outcomes included a mix of personal development (time management, self-confidence, commitment, performance under pressure, accountability, and growth through adversity), and citizenship (teamwork, leadership, and respect for others). These are concepts difficult to teach, but fundamental to holistic student development (Forbes, 2003; Miller, 2006; Myers, Sweeney, \& Witmer, 2000; Schreiner, 2009; Schreiner, Banev, \& Oxley, 2005). These educational benefits support and build upon much of the previous literature on education through athletics (e.g. Bonfiglio, 2011; Chalfin et al., 2015; Hirko, 2009; HowardHamilton \& Sina, 2001; Singer, 2008; Pascarella \& Terenzini, 2005; Videon, 2002; Weight et al., 2014; Weight et al., 2015).

Kolb (1984) outlines the learning process through four cyclical stages: concrete experiences, reflective observation, abstract conceptualization, and active experimentation. Undoubtedly, the experiences attained through participation in intercollegiate athletics provide unique concrete experiences (e.g. performing under pressure in front of 50,000 fans, training with world-class coaches, experiencing intense moments of success and failure, extending physical capabilities to personal limits, and working toward a common goal with a team). Yet, depending on the influence of the coaches, mentors, or courses which encourage reflection, conceptualization and application of the experiences, the learning cycle may not be complete. Conversely, concepts of citizenship and personal development can be richly discussed though courses that provide venues for reflective observation and abstract conceptualization, but often do not facilitate opportunities for concrete experiences or active experimentation.

Because ELT is cyclical, when essential steps to the learning process (e.g. active reflection) are not integrated into the learner-experience, concepts are not brought to life within the mind of the learner (Kolb, 1984). Academic leaders, therefore, seem to be missing a tremendous opportunity to facilitate rich educational experiences through the academic discussion, analysis, and application of these unique athletic opportunities if they are not integrated into the fabric of the traditional educational environment through curricula that can pair experiences with the additional three experiential learning phases. 
An applied sport psychology, strength and conditioning, or injury care seminar, for example, could facilitate these three additional steps to the experiential learning cycle for varsity and club-sport athletes. Alternatively, coaches and athletics support staff could be given a curriculum to address as they are integrated into the academic fold of the institution and recognized as educators (Weight, Cooper, \& Popp, 2015).

In order to understand whether learning is transpiring in spite of the lack of a traditionally structured learning environment, we now turn our attention to research questions three and four, which examine health measures and literacy of athletes and nonathletes.

\section{Health Measures and Literacy}

Interestingly, only two athlete-respondents (1\%) mentioned maintaining fitness \& health as an educational benefit of participation, and none mentioned learning about nutrition, health, or injury recovery as educational elements of their experience, though this research indicates each of these are educational derivatives of the athletics experience. In basic physiological measures of athletes and active undergraduates, stratification between the subgroups demonstrated significant differences in body fat percent with athletes producing a healthier/lean physique compared to a normal/overweight mean categorization for both men and women non-athlete undergraduates. This is intuitive considering the activity levels of varsity athletes, but the long-term holistic benefits of participation in intercollegiate athletics are often not acknowledged as an element of educational development, and research has demonstrated tremendous overall wellness benefits of those who perceive their health to be good, i.e. lower susceptibility to future metabolic risk factors (Baker et al., 2003; Huang \& Chiou, 1997; Institute of Medicine, 2004). Though long-term health benefits were not captured in this study, this would be an interesting area of future research to explore given the higher health measures and literacy within the athlete population.

Perhaps the more compelling findings are the significant differences between athlete and non-athlete populations relative to health literacy. Even though the nonathletes in the sample were enrolled in courses where health-topics were covered, nutrition, health, and injury recovery knowledge was significantly greater within the athlete-population. Participation in high school sport was also related to greater health literacy (capturing many of the athletes within that group), but the widest mean differences on each of the health literacy measures were between athletes and nonathletes. Thus, this data provides some evidence to support a hypothesis that there is education transpiring despite the general lack of formal courses to support this learning. The education, then, is perhaps occurring through simple concrete experience or other facets of the experiential learning process (Kolb, 1984) rather than in formal learning environments.

This measure of athlete learning provides an important addition to the literature exploring the role of athletics within the academy. Previous research has supported many of the educational benefits mentioned by the athletes in this study (e.g. enhanced time management, self-discipline, and leadership skills) (Adler \& Adler, 1991; Astin, 1993; Bowen \& Levin, 2003; Chalfin et al., 2015; Howard-Hamilton \& Sina, 2001; Long \& Caudill, 1991; Pascarella \& Terenzini, 2005; Rishe, 2003; Umbach et al., 2006; Weight et al., 2014). Based on this research, we may add to the list of probable educational benefits: 
enhanced body awareness, health literacy, and health - fundamental elements of a holistic educational approach which evaluates the education experience as a comprehensive endeavor integrating physical, mental, emotional, social, and spiritual dimensions of humanity preparing students for success in life (Forbes, 2003; Miller, 2006; Myers, Sweeney, \& Witmer, 2000; Schreiner, 2009; Schreiner, Banev, \& Oxley, 2005; Singer, 2008; Videon, 2002; Weight et al., 2014; Weight et al., 2015; Weight, 2015).

These findings, though enlightening, remain troubling when the scores of overall knowledge are viewed in context. For example, the mean score for athlete nutrition knowledge was a 4.57. Derived from a 10-question nutrition knowledge quiz, this score indicates the mean percentage of questions answered correctly by the athlete-sample was $45.7 \%$. While this score was higher than the active non-athlete sample by $12.2 \%$, it is still quite low. Given the intense training regimen of the athlete population, the lack of nutrition knowledge is concerning. The higher athlete score indicates that by some means, the athletes have a greater knowledge of basic nutrition than their non-athlete peers. Perhaps this learning has been acquired through trial and error, perhaps it has been attained through nutrition seminars their team or department has facilitated with a sport nutritionist, or perhaps the athletes have studied nutrition because of their passion for elite physical performance.

The sample of Power 5 institutions was selected purposefully. It is this echelon of athletics programs that is under the most scrutiny, demands the greatest commitment from its athletes, and includes athletics departments with the greatest resources. One consequence of the arms race led by these institutions has been the organizational isolation of the new buildings, organizational structures, and internal programming (Duderstadt, 2012; Frey, 2012) exacerbating athlete feelings of "otherness" due to time demands (Adler \& Adler, 1991), racial isolation (Rhoden, 2010; Sellers, Kuperminc, \& Damas, 1997), and academic isolation in the form of major clustering (Fountain \& Finley, 2009; Fountain \& Finley, 2011; Schneider, Ross, \& Fisher, 2010).

Building on the foundation of literature outlining the educational benefits of intercollegiate athletics, perhaps one route to closing the chasm between athletics and the academy is to legitimize and enhance education through athletics by building academic bridges (Weight et al., 2015). Based on the findings within this study, there is evidence that some amount of learning is occurring through participation in intercollegiate athletics, just as learning occurs though participation in band, theatre, or debate (Brand, 2006). These experiences could be enhanced by facilitating opportunities to learn through reflection on doing (Kolb, 1984; Patrick, 2011) through academic seminars designed to be paired with student experiences, a recognition of coaches as educators who are held to specific curricular guidelines (Weight et al., 2015), or a development of majors or minors that recognize elements of sport as education. By recognizing the art and science of athletics as an academic discipline similar in educational structure to music or dance, and complimentary in academic philosophy to sport management, physiology, sociology, history, ethics, anthropology, communication, economics, etc., we might facilitate tremendous opportunities for education welcome to all students interested in studying elite performance (Brand, 2006; Weight, 2015; Weight et al., 2015). This philosophical and organizational legitimacy could enable crossroads of shared passion, discovery, experience, and discussion between traditional students who participate in club sport or other forms of elite performance and varsity athletes who choose to take elite 
performance courses, and faculty with content expertise in performance psychology, strength and conditioning, nutrition, public speaking, team building, leadership, sport sociology, etc. These crossroads might bridge athletic experiences (whether varsity, recreational, or club) with the other elements of the experiential learning cycle (Kolb, 1984), and enhance the holistic education of every university student.

\section{Limitations \& Future Research}

While this study presents many recommendations and implications for higher education professionals, specific limitations must also be presented and considered. First, scholars and higher education professionals must consider that this sample is not representative of the target population. It should be noted there is an overrepresentation of white females - particularly in the athlete population. In addition, there is a noted lack of revenue sport athlete representation. These sampling errors are addressed through analysis of the gender, "revenue" sport, and ethnicity independent variables within this research, but it would be wise for future researchers to design the sampling approaches to alleviate this error, perhaps by utilizing proportional quota sampling. Another element of the sample that could alter the findings relate to the non-athlete sample. This study compared active undergraduate students enrolled in a lifetime fitness course with varsity athletes. Comparison with undergraduate students who are not enrolled in a healthrelated course could alter the findings.

A second limitation relates to the measures of health and health knowledge. This study provides only snapshot of self-reported physiological data and knowledge of current students and does not consider longitudinal data, or more comprehensive measures of knowledge. Though reliability and validity measures were taken to enhance the data collection instruments, there are limitations given the length of time between body-fat testing and survey dissemination, and the length of the instruments measuring health literacy. Finally, this study only includes NCAA Division I Power 5 institutions, thus results cannot be widely generalized to other divisions as findings could be very different in other NCAA and governing body divisions.

Moving forward, it would be of heightened interest for researchers to further explore and test the educational value of intercollegiate athletics within institutions by modeling an educational approach. Knowledge held by coaches could be assessed in an effort to understand whether proper knowledge is held by those in leadership roles and how much of an effort the coaches make to educate their athletes on nutrition, health, and injury-recovery topics. Scholars may also consider a study design that defines elements to a holistic education during the undergraduate experience and explores methods to most effectively foster this growth. Similarly, student-learning outcomes and knowledge retention could be measured by comparing students in a nutrition or health course, with athletes and active students who pair their experiences in athletics with a nutrition or health course taught through an ELT methodology. This could provide a foundation for future research in effective teaching and learning methods utilizing experiential learning and education through athletics. 


\section{References}

Adler, P. \& Adler, P. (1991). Backboards \& blackboards: College athletes and role engulfment. New York, NY: Columbia University Press.

Anderson, M. L. (2008). Multiple inference and gender differences in the effects of early intervention: A reevaluation of the abecedarian, perry preschool, and early training projects. Journal of the American Statistical Association, 103(484), 14811495.

Anthes, R. (2010, March 7). Rutgers 1000 fights big spending as focus drifts from academics. The Daily Orange. Retrieved from http://www.dailyorange.com/2.8655/rutgers-1000-fights-big-spending-as-focusdrifts-from-academics-1.1240226

Antonio, J. (2008). Essentials of sports nutrition and supplements. Totowa, NJ: Humana Press.

Astin, A. W. (1993). What matters in college? Four critical years revisited. San Francisco, CA: Jossey-Bass.

Baker, L., Wagner, T. H., Singer, S., \& Bundorf, M. K. (2003). Use of the Internet and email for health care information: Results from a national survey. Journal of the American Medical Association, 289(18), 2400-2406. doi:10.1001/jama.289.18.2400

Barber, J. P. (2012). Integration of learning a grounded theory analysis of college students' learning. American Educational Research Journal, 49, 590-617.

Benford, R. (2007). The college sports reform movement: Reframing the "edutainment" industry. The Sociological Quarterly, 48(1), 1-28.

Bennett, B. (2014, August 8). NCAA board votes to allow autonomy. ESPN.com. Retrieved from: http://espn.go.com/college-sports/story/_id/11321551/ncaaboard-votes-allow-autonomy-five-power-conferences

Blann, F. (1985). Intercollegiate athletic competition and students' educational and career plans. Journal of College Student Personnel, 26, 115-118.

Bonfiglio, R. A. (2011). Intercollegiate athletic programs deepening their educational impact. About Campus, 16(3), 29-32.

Bowen, W. G., \& Levin, S. A. (2003). Reclaiming the game: College sports educational values. Princeton, NJ: Princeton University Press.

Brand, M. (2006). The role and value of intercollegiate athletics in universities. Journal of the Philosophy of Sport, 33, 9-20.

Bremmer, D. \& Kesselring, R. (1993). The advertising effect of university athletic success: A reappraisal of the evidence. Quarterly Review of Economics and Finance, 33(4), 409-421.

Bruening, J. E., Madsen, R. M., Evanovich, J. M., \& Fuller, R. D. (2010). Discovery, integration, application and teaching: Service learning through sport and physical activity. Sport Management Education Journal, 4(1), 31-48.

Byers, W., \& Hammer, C. (1995). Unsportsmanlike conduct: Exploiting college athletes. Ann Arbor: University of Michigan Press.

Chaddock, L., Neider, M. B., Voss, M. W., Gaspar, J. G., \& Kramer, A. F. (2011). Do athletes excel at everyday tasks?. Medicine and Science in Sports and Exercise, 43(10), 1920. 
Chalfin, P., Weight, E. A., Osborne, B., \& Johnson, S. (2015). The value of intercollegiate athletics participation from the perspective of employers who target athletes. Journal of Issues in Intercollegiate Athletics, 1-27.

Chaves, C. (2006). Involvement, development, and retention: Theoretical foundations and potential extensions for adult community college students. Community College Review, 34, 139-152.

College Sport Research Institute (2014). Adjusted graduation gap report: NCAA FBS football. Retrieved from: http://csriconference.org/home/wpcontent/uploads/2013/10/2014-FOOTBALL-AGG-REPORT_10-7-14.pdf

Desrochers, D. (2013). Academic spending versus athletic spending: Who wins? Washington, DC: American Institutes for Research.

Dixon, N. M., Adams, D.E., \& Cullins, R. (1997). Learning style assessment. In L. J. Bassi, \& D. F. Russ-Eft (Eds.), Assessment, Development, and Measurement (3764). Alexandria, VA: American Society for Training and Development.

Dosh, K.A. (2014, August 7). New NCAA governance structure approved. FoxSports.com. Retrieved from: http://www.foxsports.com/collegefootball/outkick-the-coverage/new-ncaa-governance-structure-approved-080714

Drape, J., \& Thomas, K. (2010, September 2). As colleges compete, the money flows to all sports. The New York Times. Retrieved from http://www.nytimes.com/2010/09/03/sports/03cup.html?scp=1\&sq=as\%20athletic $\% 20$ directors \%20compete\&st $=$ cse

Duderstadt, J. (2003). Intercollegiate athletics and the American university: A university president's perspective. Ann Arbor, MI: University of Michigan Press.

Duderstadt, J. J. (2012). Institutional control. In J. W. Satterfield, R. L. Hughes, \& K. Kearney (Eds.), Sports and Athletics in Higher Education. Boston: MA: Pearson.

Elinson, Z. (2013, June 21). Lawsuit could alter college athletics. The Wall Street Journal: A6

Forbes, S. (2003). Holistic education: An analysis of its ideas and nature. Brandon, VT: Foundation for Educational Renewal.

Fountain, J. J., \& Finley, P. S. (2009). Academic majors of upperclassmen football players in the Atlantic Coast Conference: An analysis of academic clustering comparing white and minority players. Journal of Issues in Intercollegiate Athletics, 2, 1-13.

Fountain, J.J., \& Finley, P.S. (2011). Academic clustering: A longitudinal analysis of a Division I football program. Journal of Issues in Intercollegiate Athletics. 4, 2441.

Frey (2012). Institutional control of athletics: An analysis of the role played by presidents, faculty, trustees, alumni, and the NCAA. In J. W. Satterfield, R. L. Hughes, \& K. Kearney (Eds.), Sports and Athletics in Higher Education. Boston: MA: Pearson.

Fulks, D. L. (2011). Revenues and expenses 2004-2010: NCAA Division I intercollegiate athletics programs report. Technical report, National Collegiate Athletic Association, Indianapolis, IN.

Gayles, J. G. (2009). The athlete experience. New Directions for Institutional Research, $144,33-41$. 
Gayles, J. G., \& Hu, S. (2009). Athletes as students: Ensuring positive cognitive and affective outcomes. New Directions for Higher Education, 148, 101-107.

George, D., \& Mallery, P. (2003). SPSS for Windows step by step: A simple guide and reference. 11.0 update (4th ed.). Boston: Allyn \& Bacon.

Grimes, P. W. \& Chressanthis, G. A. (1994). Alumni contributions to academics. American Journal of Economics and Sociology, 53(1), 27-40.

Hardin, R., Bemiller, J., \& Pate, J. (2013). Development and organization of a studentoperated sport management cocurricular club: Partners in sports. Sport Management Education Journal, 7(1).

Hirko, S. (2009). Intercollegiate athletics and modeling multiculturalism. New Directions for Higher Education, 148, 91-100.

Hosick, M.B. (2014, Aug 7). Board adopts new Division I structure. NCAA News. Retrieved from: http://www.ncaa.org/about/resources/media-center/news/boardadopts-new-division-i-structure

Howard-Hamilton, M. F., \& Sina, J. A. (2001). How college affects athletes. New Directions for Student Services, 93, 35-45.

Hsu, C. H. C. (1999). Learning styles of hospitality students: Nature or nurture? International Journal of Hospitality Management, 18, 17-30.

Hsu, W., Chiang, C., \& Yang, S. (2014). The effect of individual factors on health behaviors among college students: The mediating effects of eHealth literacy. Journal of Medical Internet Research, 16(12), e287. doi: 10.2196/jmir.3542

Huang, Y.H., \& Chiou, C.J. (1997). Predictors contributing to health-promoting lifestyles among college students in Kaohsiun area. Chinese Journal of Public Health, 16(1), 24-36.

Humphreys, B. R., \& Mondello, M. (2007). Intercollegiate athletic success and donations at NCAA division I institutions. Journal of Sport Management, 21(2), 265-280.

Institute of Medicine (2004). In L. Nielsen-Bohlman, A. M. Panzer \& D. A. Kindig (Eds.), Health literacy: A prescription to end confusion. Washington, DC.

Irwin, C. C., Hays, B., \& Irwin, R. L. (2011). Integrative curricular program for physical education: Classroom on the Court. Strategies, 25(2), 14-17.

Jones, C., Reichard, C., \& Mokhtari, K. (2003). Are students' learning styles discipline specific? Community College Journal of Research \& Practice, 27, 363-375.

Kolb, D. A. (1984). Experiential learning: Experience as the source of learning and development. Upper Saddle River, New Jersey: Prentice-Hall.

Lanter, J. R., \& Hawkins, B. J. (2013). The economic model of intercollegiate athletics and its effects on the college athlete educational experience. Journal of Intercollegiate Sport, 6(1), 86-95

Long, J. E., \& Caudill, S. B. (1991). The impact of participation in intercollegiate athletics on income and graduation. The Review of Economics and Statistics, 525531.

Maloney, M. T. \& McCormick, R. (1993). An examination of the role that intercollegiate athletic participation plays in academic achievement: Athletes' feats in the classroom. Journal of Human Resources. 28(3), 555-570.

Matthews, D. B. (1991). The effects of learning style on grades of first-year college students. Research in Higher Education, 32, 253-268. 
McCann, Z. (2012). Athletes more prepared for real world? Retrieved from http://espn.go.com/espn/page2/story/_id/7633078/

McCormick, R. A., \& McCormick, A. C. (2006). The myth of the athlete: The college athlete as employee. Washington Law Review, 81, 71-157.

McCormick, R. E., \& Tinsley, M. (1987). Athletics versus academics? Evidence from SAT scores. Journal of Political Economy, 95(5), 1103-1116.

McKelvey, S., \& Southall, R. M. (2008). Teaching sport sponsorship sales through experiential learning. International Journal of Sport Management and Marketing, $4(2), 225-254$.

Miller, R. (2006). Making connections to the world: Some thoughts on holistic curriculum. Encounter: Education for Meaning and Social Justice, 19(4), 19-24.

Mixon Jr., F., Trevino, L., \& Minto, T. (2004). Touchdowns and test scores: Exploring the relationship between athletics and academics. Applied Economics Letters, 11(7), 421-424.

Myers, J. E., Sweeney, T. J., \& Witmer, J. M. (2000). The Wheel of Wellness counseling for wellness: A holistic approach to treatment planning. Journal of Counseling \& Development, 78(3), 251-266.

Oriard, M. (2001). King football: Sport \& spectacle in the golden age of radio \& newsreels, movies \& magazines, the weekly \& daily presses. Chapel Hill, NC: The University of North Carolina Press.

Pascarella, E. T., \& Smart, J. C. (1991). Impact of intercollegiate athletic participation for African American and Caucasian men: Some further evidence. Journal of College Student Development. 32, 123-130.

Pascarella, E. T., \& Terenzini, P. T. (2005). How college affects students: A third decade of research. San Francisco, CA: Jossey-Bass.

Patrick, F. (2011). Handbook of research on improving learning and motivation through educational games: Multidisciplinary approaches. Ireland: Waterford Institute of Technology.

Pauline, G. (2013). Engaging students beyond just the experience: Integrating reflection learning into sport event management. Sport Management Education Journal, 7(1).

Pauline, G., \& Pauline, J. S. (2008). Teaching sport sponsorship activation through a client-based experiential learning project. Sport Management Education Journal, 2(1), 19-37.

Pescatello, L. S., \& American College of Sports Medicine. (2014). ACSM's guidelines for exercise testing and prescription (9th ed.). Philadelphia, PA: Wolters Kluwer/Lippincott Williams \& Wilkins Health.

Pierce, D., \& Petersen, J. (2010). Experiential learning in sport sales: Student perceptions of sport sales expectations, skills and preparation. Sport Management Education Journal, 4(1), 49-59.

Pope, D. G., \& Pope, J. C. (2009). The impact of college sports success on the quantity and quality of student applications. Southern Economic Journal, 75(3), 750-780.

Potuto, J. R., \& O’Hanlon, J. (2007). National study of athletes regarding their experiences as college students. College Student Journal, 41(4), 1-87.

Rhoden, W. C. (2010). Forty million dollar slaves: The rise, fall, and redemption of the black athlete. Random House LLC. 
Rishe, P. J. (2003), A reexamination of how athletic success impacts graduation rates: Comparing student-athletes to all other undergraduates. American Journal of Economics and Sociology, 62: 407-427.

Rosewater, A. (2009). Learning to play and playing to learn: Organized sports and educational outcome. Education Digest: Essential Readings Condensed for Quick Review, 75(1), 50-56.

Ross-Gordon, J. M. (2003). Adult learners in the classroom. New Directions for Student Services, 2003(102), 43-52.

Sack, A. L. \& Staurowsky, E. J. (1998). College athletes for hire: The evolution and legacy of the NCAA's amateur myth. Westport, CT: Praeger Publishers.

Saldaña, J. (2009). The coding manual for qualitative researchers. Los Angeles, CA: Sage.

Schneider, R.G., Ross, S.R., \& Fisher, M. (2010). Academic clustering and major selection of intercollegiate athletes. College Student Journal. 44(1), 64-70.

Schreiner, P. (2009). Holistic education and teacher training. In M. D. deSouza, L. F. Francis, J. O'Higgins-Norman, \& D. G. Scott (Eds.), International Handbook of Education for Spirituality, Care and Wellbeing (pp. 753-770). The Netherlands: Springer.

Schreiner, P., Banev, E., \& Oxley, S. (Eds.). (2005). Holistic education resource book: Learning and teaching in an ecumenical context. Waxmann Verlag.

Sellers, R. M., Kuperminc, G. P., \& Damas, A. (1997). The college life experiences of African American women athletes. American Journal of Community Psychology, 25(5), 699-720.

Shames, W., \& Alden, P. (2005). The impact of short-term study abroad on the identity development of college students with learning disabilities and/or AD/HD. Frontiers: The Interdisciplinary Journal of Study Abroad, 11, 1-31.

Shields, S. A., Mallory, M. E., \& Simon, A. (1989). The body awareness questionnaire: Reliability and validity. Journal of Personality Assessment, 53(4), 802-815.

Singer, J. N. (2008). Benefits and detriments of African-American male athletes' participation in a big-time college football program. International Review for the Sociology of Sport, 43, 399-408.

Smith, R. (1988). Sports and freedom: The rise of big-time college athletics. New York, NY: Oxford University Press.

Smith, R. (2011). Pay for play: A history of big-time college athletic reform. Urbana, Chicago, and Springfield, Illinois: University of Illinois Press.

Sneed, T. (2014, Aug 8). Experts question whether NCAA reform really helps athletes. US News \& World Report. Retrieved from:

http://www.usnews.com/news/articles/2014/08/08/experts-question-whether-ncaareform-really-helps-athletes

Soshnick, S. (2013). Wall street hires losers turned winners after college athletics. Retrieved from http://www.bloomberg.com/news/2013-10-16/wall-street-hireslosers-turned-winners-after-college-athletics.html

Southall, R. M., Nagel, M. S., LeGrande, D., \& Han, P. (2003). Sport management practica: A metadiscrete experiential learning model. Sport Marketing Quarterly, 12(1), 27-36. 
Southall, R. M., \& Weiler, J. D. (2014). NCAA Division-I Athletic Departments: 21st Century athletic company towns. Journal of Issues in Intercollegiate Athletics, 7, 161-186.

Sowa, C. \& Gressard, C. (1983). Athletic participation: Its relationship to student development. Journal of College Student Personnel, 24, 236-239.

Spence, K. K., Hess, D. G., McDonald, M., \& Sheehan, B. J. (2009). Designing experiential learning curricula to develop future sport leaders. Sport Management Education Journal, 3(1), 1-25.

Sperber, M. A. (2000). Beer and circus: How big-time college sports is crippling undergraduate education. New York, NY: Henry Holt and Co.

Stellefson, M., Hanik, B., Chaney, B., Chaney, D., Tennant, B., \& Chavarria, E. A. (2011). eHealth literacy among college students: a systematic review with implications for eHealth education. Journal of Medical Internet Research, 13(4), e102. doi:10.2196/jmir.1703

Stevens, M. (2007). Creating a class: College admissions and the education of elites. Cambridge, MA: Harvard University Press.

Stone, J. \& Strange, C. (1989). Quality of student experiences of freshmen intercollegiate athletes. Journal of College Student Development, 30, 148-154.

Streiner, D. L. (2003) Starting at the beginning: an introduction to coefficient alpha and internal consistency, Journal of Personality Assessment, 80, 99-103.

Teranishi, C. S. (2007). Impact of experiential learning on Latino college students' identity, relationships, and connectedness to community. Journal of Hispanic Higher Education, 6, 52-72.

Terlep, S. (2014, Aug 7). NCAA votes to give big conferences more autonomy. The Wall Street Journal. Retrieved from http://online.wsj.com/articles/ncaa-votes-to-givebig-conferences-more-autonomy-1407433146

Thelin, J. (1996). Games colleges play: Scandal and reform in intercollegiate athletics. Baltimore, MD: Johns Hopkins University Press.

Toma, D. (1999). The collegiate ideal and the tools of external relations: The uses of high-profile intercollegiate athletics. New Directions for Higher Education, 105, 81-90.

Tucker, I. B. \& Amato, L. (2003). Does big-time success in football or basketball affect SAT scores? Economics of Education Review, 12(2), 177-181.

Umbach, P. D., Palmer, M. M., Kuh, G. D., \& Hannah, S. J. (2006). Intercollegiate athletes and effective educational practices: Winning combination or losing effort? Research in Higher Education, 47(6), 709-733.

United States Department of Health and Human services. (2010). Healthy People. Washington DC: US Government Printing Office.

University Learning Outcomes Assessment (UniLOA). (2011). Intercollegiate athletes report of means. Retrieved from http://www.measuringbehaviors.com/AthletesFinal2011.pdf.

Videon, T. M. (2002). Who plays and who benefits: Gender, interscholastic athletics, and academic outcomes. Sociological Perspectives, 45(4), 415-444.

Walker, H. J., \& Lim, J. (2007). Event management: From the classroom to the real world: A case study. The Journal of Research in Health, Physical Education, Recreation, Sport \& Dance, 2, 40-46. 
Watson, J. C., \& Kissinger, D. B. (2007). Athletic participation and wellness: Implications for counseling college athletes. Journal of College Counseling, 10, 153-162.

Weight, E. A. (2015, March 23). Time to embrace the art and science of college sports. The Chronicle of Higher Education. Retrieved from: http://chronicle.com/article/228665/

Weight, E.A., \& Cooper, C.G. (2012, May). Scandal, scholarship, and subsidy: An analysis of intercollegiate athletic coverage within five major newspapers. Presentation for the North American Society of Sport Management Conference, Seattle, WA.

Weight, E.A., Cooper, C., \& Popp, N.K. (2015). The coach-educator: NCAA Division I coach perspectives about an integrated university organizational structure. Journal of Sport Management. 29, 510-522.

Weight, E.A., Navarro, K., Huffman, L., \& Smith-Ryan, A. (2014). Quantifying the psychological benefits of intercollegiate athletics participation: Implications for higher education policy and practice. Journal of Issues in Intercollegiate Athletics. 7, 390-409.

Weight, E.A., \& Zullo, R. H. (2015). Administration of intercollegiate athletics. Champaign, IL: Human Kinetics.

Williams, D. (2013). Why You Should Fill Your Company With 'Athletes'. Retrieved from http://www.forbes.com/sites/davidkwilliams/2013/10/02/why-you-should-fillyour-company-with-athletes/

Wolf-Wendel, L. E., Douglas, J. T., \& Morphew, C. C. (2001). There's no "I" in "team": Lessons from athletics on community building. The Review of Higher Education, 24, 369-396.

Wolken, D. (2014, Aug 7). NCAA board approves Division I autonomy proposal. USA Today. Retrieved from: http://www.usatoday.com/story/sports/college/2014/08/07/ncaa-board-ofdirectors-autonomy-vote-power-five-conferences/13716349/

Younes, M. N., \& Asay, S. M. (2003). The world as a classroom: The impact of international study experiences on college students. College Teaching, 51, 141147.

Zimbalist, A. (1999). Unpaid professionals: Commercialism and conflict in big-time college sports. Princeton, NJ: Princeton University Press. 